\title{
A literature review on park-and-rides
}

\author{
Antora Mohsena Haque \\ University of Tennessee, Knoxville \\ ahaque1@vols.utk.edu \\ Shahrbanoo Rezaei \\ University of Tennessee, Knoxville \\ srezaei@vols.utk.edu
}

\author{
Candace Brakewood \\ University of Tennessee, Knoxville \\ cbrakewo@utk.edu \\ Anahita Khojandi \\ University of Tennessee, Knoxville \\ khojandi@utk.edu
}

\begin{abstract}
American cities have been implementing park-and-rides (PNRs) since the 1930s; however, there has been a recent resurgence of literature examining this type of transit station. This paper aims to provide a comprehensive review of the current literature on PNRs and directions for future research. PNR studies published in the last ten years were reviewed and text mining was applied to extract key themes. Six themes were identified. The two most common areas of research were network equilibrium and optimization (12 of 37 studies) and demand models (8 of 37 studies). This was followed by guidelines and best practices as well as comparative studies (6 of 37 studies each). Parking utilization had the fewest number of recent studies (3 of 37 studies). This review revealed that the majority of PNR studies were conducted in geographic areas with extensive transit services, most studies have focused on rail-based PNRs, and the most widely used method was multinomial logit. Some areas for future research include studying remote PNRs, examining bus-based PNRs, and assessing the impact of emerging modes on PNR utilization. This systematic review could assist planners and transit agencies in further improving sustainable PNR networks in their cities.
\end{abstract}

\section{Introduction}

Park-and-ride (PNR) facilities are commonly used in transit systems worldwide (Wang, Meng, \& Zhang, 2014). By definition, PNRs are parking spaces at transit stations where commuters park their automobiles and take a bus or train to reach their destination. Commuters retrieve their automobiles from PNRs on their way back. Common locations for PNRs are suburbs or outer edges of cities. Key advantages of PNRs include providing access to rail and commuter bus services, providing alternatives to automobiles, providing space for carpooling/vanpooling, enabling transit service in low-density areas, and relieving neighborhoods from informal on-street parking. More use of this intermodal service is expected to reduce vehicle miles traveled (Cherrington et al., 2017) and assist in achieving sustainable mobility patterns (Tennøy et al., 2020). However, the potential of PNRs may not be fully realized (Chen et al., 2017) for various reasons, like unattractive locations of PNRs (Chen et al., 2014). To achieve a sustainable PNR network, a comprehensive understanding of PNRs is vital. There have been

Copyright 2021 Antora Mohsena Haque, Candace Brakewood, Shahrbanoo Rezaei \& Anahita Khojandi http://dx.doi.org/10.5198/jtlu.2021.1923

ISSN: 1938-7849 | Licensed under the Creative Commons Attribution - Noncommercial License 4.0

The Journal of Transport and Land Use is the official journal of the World Society for Transport and Land Use (WSTLUR) and is published and sponsored by the University of Minnesota Center for Transportation Studies. 
numerous prior studies on the placement and attributes of PNRs, and this presents an opportunity to synthesize findings and identify gaps in the literature. Moreover, organizing and summarizing new and recent literature may help planners and policymakers implement PNRs that better serve their local communities.

Therefore, the objective of this paper is to synthesize the literature of the past ten years on PNRs and provide directions for future studies. This paper is organized as follows: first, the method for the literature review is explained and text mining is applied to the studies to identify themes. Next, literature within each theme is reviewed, gaps are identified, and future directions are provided. Finally, the key findings are discussed, and the implications are suggested.

\section{$2 \quad$ Method}

\subsection{Data collection}

This section describes the method used to search, compile, and categorize the literature for this review. The types of publications considered for this review were peer-reviewed journal articles, conference proceedings, theses or dissertations, Transit Cooperative Research Program (TCRP) reports of the Transportation Research Board (TRB), publicly available planning documents, and guidelines or toolkits from state department of transportations (DOT). Papers from the United States and those considering hypothetical contexts were included. The following keywords and phrases were searched either in combination or separately: "park-and-ride," "PNR," "TCRP," "planning guideline," "guideline," and "toolkit."

The literature search was conducted in August 2019 and was updated again in July 2020. Two electronic databases, namely Google Scholar and Transport Research International Documentation (TRID), were used. As PNRs have been a topic of interest for a long time, the initial search provided results that dated back to the 1970s. The narrowed search range spanned from 2011 till July 2020. Thirty-seven studies were found, which constitute the final samples of papers reviewed in the following sections. Publications from the last ten years were selected for several reasons. First, recent publications should build upon prior work. Second, a period of ten years was deemed sufficiently long time to observe trends in recent years given the number of prior studies published during this period. Figure 1 shows the frequency distribution of the publication types of PNR studies in the last ten years.

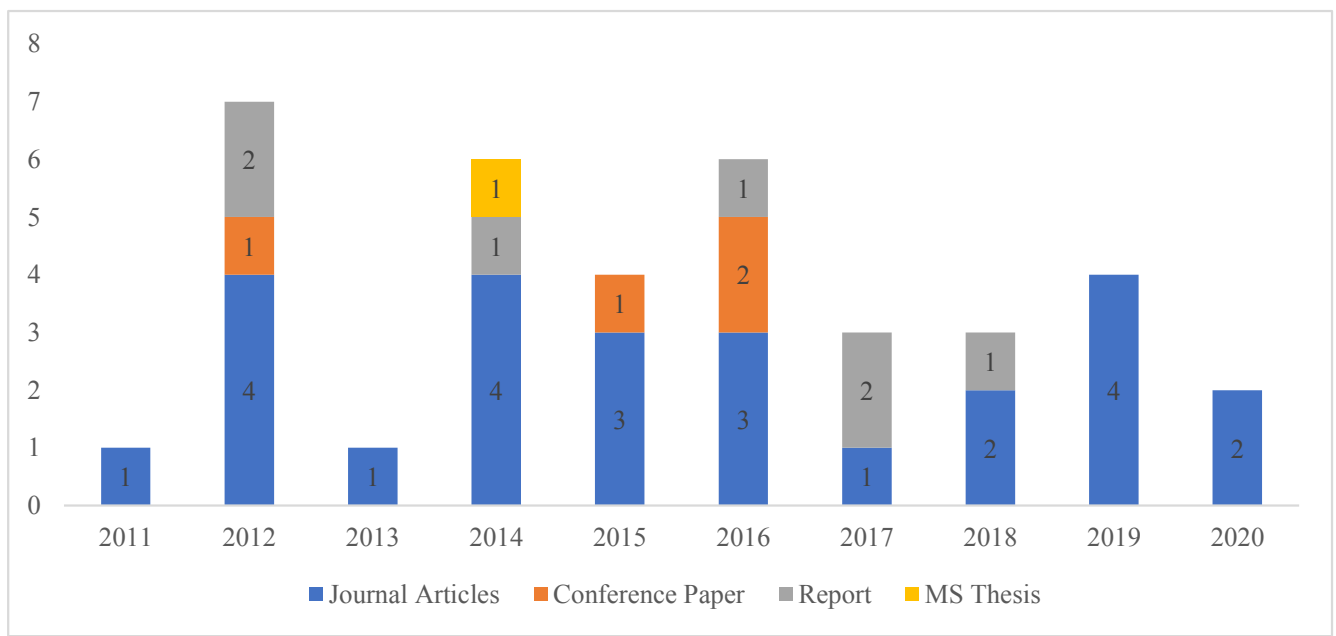

Figure 1. Number of studies included in this review per their year of publication from 2011-2020 $(\mathrm{n}=37)$ 
In total, 25 journal articles, seven reports, four conference proceedings, and one thesis were published in the last ten years. Among them, three were TCRP reports, two were transportation institute provided reports, and two were state department of transportation (DOT) design guidelines that were available online. After the data collection process, a text-mining method was applied to identify the themes of PNR research.

\section{$2.2 \quad$ Text mining}

The authors utilized text-mining methods to classify the existing PNR-based studies. As text-mining helps discover knowledge from unstructured textual data (Feldman \& Dagan, 1995), classifying PNR studies based on the words used in the documents is a simple scientific approach rather than doing it manually. In the text-mining process, the available documents were preprocessed to reconstruct the missing data structure. Then dimension reduction techniques were applied to make the text-mining results interpretable (Rajman \& Vesely, 2004). QDA Miner (Péladeau, 2004) and WordStat software (Provalis Research, 2014) were used for text-mining. In this paper, the selected 37 studies were first appended in the QDA Miner. Then, WordStat was used to run the content analysis and prepare a cooccurrences map as shown in Figure 2.

The cooccurrences map used multidimensional scaling (MDS) to graphically represent the proximity values computed on all included keywords. The dependent keywords occurred close to each other on the map. The connecting lines in the figure represent the strength of the association between these dependent keywords. Keywords of distinct colored clusters were observed to identify different themes. In this co-occurrences map, the green cluster contained keywords like "authority," "design," and "standards." As these words were frequently observed in PNR guidelines-based publications, "Guidelines and Best Practices" was identified as one theme. The yellow cluster included keywords like "hour," "rates," "efficiency," and "circulation," which indicated utilization of parking spaces. In contrast, this cluster also had keywords like "Greenhouse Gas (GHG)," "Vehicle Kilometer Travelled (VKT)," and "emissions," which were used for comparing PNRs with Transit-Oriented-Developments (TODs). Therefore, two distinct themes were detected from the yellow cluster, namely "Comparative Studies" and "Parking Utilization." The orange cluster contained keywords like "demand," "supply," "logit," and "auto," which was named the "Demand Model" theme. The orange cluster also contained keywords like "network," "equilibrium," and "algorithm," and this was titled the "Network Equilibrium and Optimization" theme. The blue cluster was deemed to be "Other" because no specific theme was identified from its keywords. Thus, six major themes were identified from the four distinct clusters. Last, there were some other very small clusters, but they did not form a significant theme. 


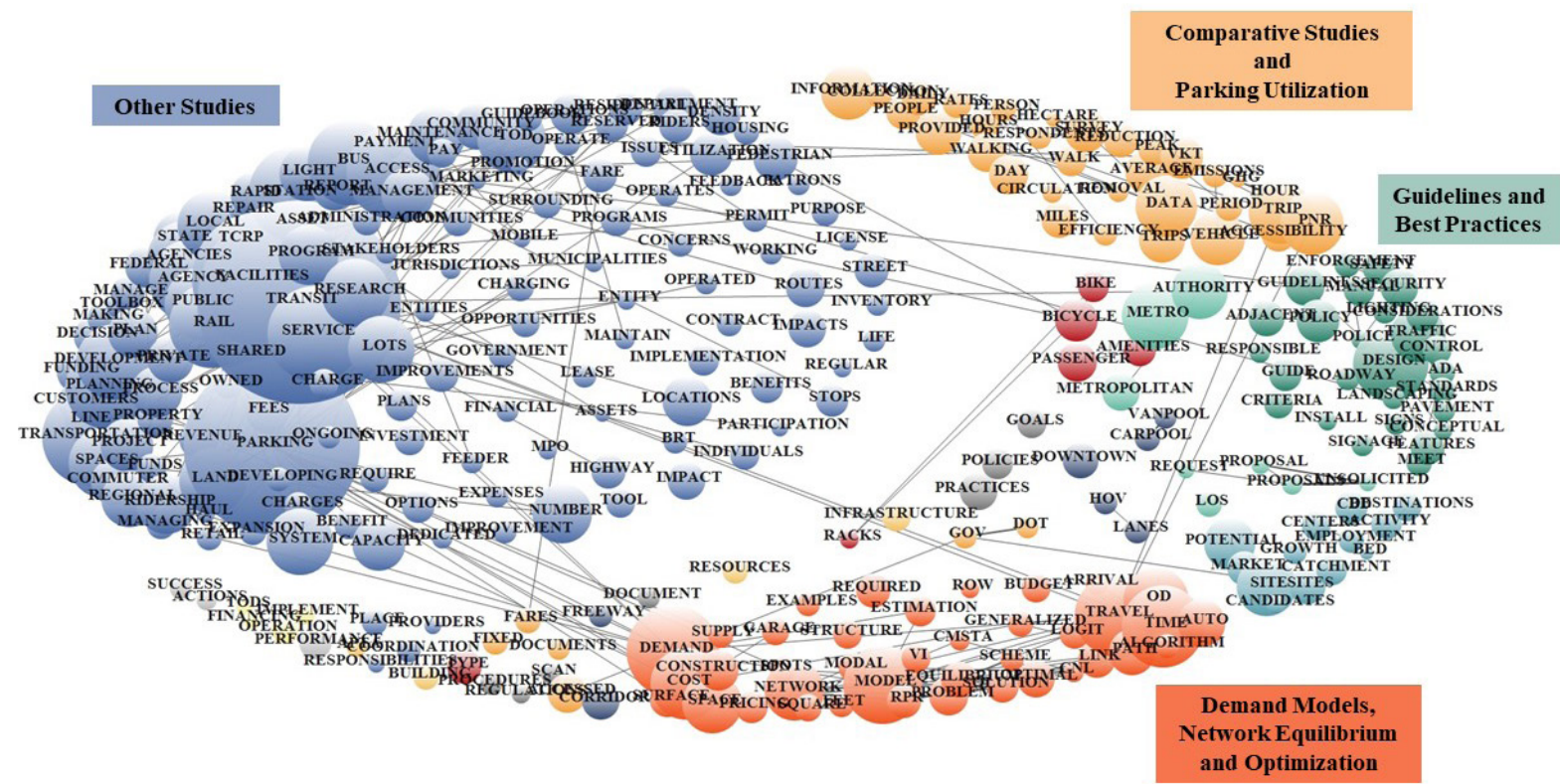

Figure 2. Co-occurrences map of studies on PNRs by QDA text mining tool

Based on the word clusters of the co-occurrences map, six themes of PNR studies were identified, which are described as follows:

1. Comparative Studies: These studies consisted of comparative analyses between PNR and Transit Oriented Development (TOD), between rail-based PNR and bus-based PNR, or between PNR trips and single occupancy vehicle (SOV) trips.

2. Guidelines and Best Practices: These studies explained the characteristics of successful PNRs and design recommendations for them. TCRP reports and guidelines by state DOTs on PNRs fell into this theme.

3. Demand Models: These studies applied different logit models to identify what factors influenced a rider's mode choice or PNR station choice.

4. Network Equilibrium and Optimization: These studies used different mathematical programming algorithms and optimization techniques to solve PNR network equilibrium problems.

5. Parking Utilization: These studies considered parking space utilization at PNRs.

6. Other: The remainder of the studies fell into this broad theme that considered all other topics.

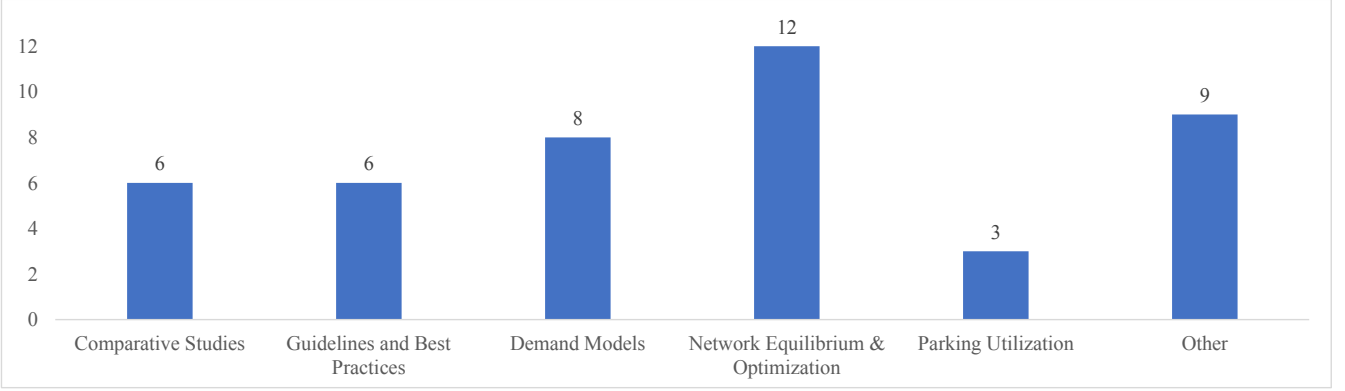

Figure 3. Number of reviewed studies under each theme from 2011-2020 $(\mathrm{n}=37$; some studies counted multiple times)

Figure 3 shows the distribution of publications for the six themes. Depending on the scope and method, some publications were discussed under more than one theme. As shown in Figure 3, in the 
last ten years, most research was conducted in the Network Equilibrium and Optimization theme (12 of 37 studies, or 32\%). The next most common area of interest was Demand Models (8 of 37 studies, or 21.62\%). This was followed by Guidelines and Best Practices and Comparative Studies (6 of 37 studies, or $16.24 \%$ each). Parking Utilization had the fewest recent studies (3 of 37 studies, or $8 \%$ ). Although the Other theme also had a higher number of studies ( 9 of 37, 24\%), these studies focused on different topics. The key findings for each of these themes are summarized in the next section.

\section{$3 \quad$ Results}

\subsection{Theme 1: Comparative studies}

A chronological summary of the most relevant studies pertaining to the theme of Comparative Studies is provided in Table 1. As shown in Table 1, six studies were reviewed, of which four were journal articles, one was a thesis, and one was a conference paper. Five out of six studies were in real world settings, and one study was in a hypothetical scenario (Fan et al., 2016). Four studies were on rail-based PNRs (Duncan, 2019; Fan et al., 2016; Martin \& Hurrell, 2012; Truong \& Marshall, 2014) and two studies were on both rail-based and bus-based PNRs (Palakurthy et al., 2017; Zhang, 2014).

Key findings from the Comparative Studies are described here. Different studies considered different factors. Comparisons based on transit ridership, parking cost, parking structure type, vehicle kilometers traveled (VKT), vehicle hours of delay (VHD), development density, and residential demand calculations (Duncan, 2019; Fan et al., 2016; Martin \& Hurrell, 2012) were seen in PNR and TOD based studies. PNRs performed better than TODs in locations farthest from downtowns (11-13 km) in terms of VKT reduction (Duncan, 2019). PNR trips were compared to SOV trips, and end-of-line PNRs resulted in lesser vehicle mileage, fuel consumption, and Green House Gas (GHG) emissions (Truong \& Marshall, 2014). Rail-based and bus-based PNRs were compared in terms of parking space utilization rates (Zhang, 2014) and trip generation rates (Palakurthy et al., 2017). Rail-based PNRs were observed to have higher utilization rates than bus-based PNRs. The application of sophisticated statistical models was rare in Comparative Studies. Only one in six studies used the Tobit model to predict PNR demand and reported that Tobit was a better model to predict bus-based PNR demand (Zhang, 2014).

Some strengths and weaknesses of these Comparative Studies are identified here, which also help to identify research gaps. One strength of these six Comparative Studies is that these studies are able to help transit agencies and cities choose between PNRs and TODs for their transit stations and help reduce the cost of developing stations. One weakness of these Comparative Studies is that they do not provide solutions to improve the performance of inner corridor PNRs. Another weakness of the PNR-TOD comparative studies is that they ignore TODs in office and mixed use areas and only compare residential area TODs with PNRs. Comparison between rail and bus-based PNRs and TODs is also missing from this theme.

Numerous areas for future research emerged from the gaps found in the Comparative Studies. First, a comparison between PNRs and TODs for Bus Rapid Transit (BRT) or express bus services would be valuable for future studies since many cities in the United States do not have rail services. Second, studies might consider equity issues (Fan et al., 2016) when comparing PNRs to TODs because not everyone has access to cars, which by definition are needed to access a PNR. Third, other trip purposes (beyond work trips) could be considered to see which facility (TOD versus PNR) causes more VKT reductions.

\subsection{Theme 2: Guidelines and best practices}

In this theme, studies that consisted of design Guidelines and Best Practices of PNRs are summarized, and key findings are presented in Table 2. In total, five reports were reviewed; three were TCRP reports 
(Cherrington, Brooks, Cardenas, Elgart, Galicia, Hansen, et al., 2017; Cherrington, Brooks, Cardenas, Elgart, Galicia, Hansen, Miller, et al., 2017; Coffel et al., 2012) and two were state DOT guidelines for PNRs (AECOM, 2012; VDOT, 2018) that were available online. One journal article was also reviewed, which addressed gaps in these guidelines. All these documents were for both rail-based and bus-based PNRs.

Key findings from the TCRP reports, state guidelines, and the article are described here. The TCRP reports on PNRs were TCRP Report 192, Report 153, and Report 69, which summarized the suggested design dimensions and locations of PNRs for different area types of US. The distance where PNRs could be placed from a city center ranged between 10-25 miles, and none of the guidelines suggested to locate PNRs near the city center. It could be inferred that PNRs are most likely to succeed in the farthest locations from the city center. Good accessibility from highways, visibility, and security were encouraged to obtain successful PNRs. TCRP Report 69 discussed PNR Demand Models prepared by the Federal Transit Administration (FTA), by various transit agencies, and by researchers. The predictors for transit ridership associated with PNRs were similar in these models. The geographic unit of analysis in most of the models was the half-mile area around the transit stations. The state DOT guidelines were from the Florida Department of Transportation (FDOT) (AECOM, 2012) and the Virginia Department of Transportation (VDOT) (VDOT, 2018). The former provided comprehensive guidelines on PNR lot design and dimensions, and the latter offered distinct guidelines for PNRs of high density, medium density, and low density areas. However, these existing Guidelines and Best Practice reports did not document some important but contradictory PNR location decisions, which were identified by Mock and Thill (2015). These researchers reported that PNR location preferences might differ between planners and transit agency managers. For locating PNRs, transit planners in larger cities often prioritized proximity to residential areas and the relationship to the CBD over proximity to highways and congested thoroughfares. Transit agency managers of larger cities often considered PNR demand before land uses, but those of mid-tier cities often placed land-use considerations over PNR demand. Transit planners also considered capital costs as a crucial factor in determining which rapid transit stations should have PNRs.

Some strengths and weaknesses of the Guidelines and Best Practices theme are identified here, which also help to identify research gaps. One strength of the Guidelines and Best Practices studies is that these works synthesize and summarize general PNR-related guidelines. A weakness of these types of studies is that their findings are not universal and might need to be updated with ever-improving transportation technology, newer modes, and planning practices.

There are several gaps in the literature of the Guidelines and Best Practices theme. There is a scarcity of PNR design guidelines for specific cities or states published on the internet. Guidelines for planning, designing, and managing PNRs as per TCRP reports are for the entire United States. However, transit systems and ridership vary between big cities, small cities, suburbs, and rural areas. Hence, states and cities may want to have specific guidelines or toolkits for their respective regions.

\subsection{Theme 3: Demand models}

A summary of the most relevant studies pertaining to the theme of Demand Models is provided in Table 3, and they are organized chronologically. As shown in Table 3, eight studies were reviewed, six were journal articles, one was a report, and one was a thesis. Six studies were in different US cities and two studies considered hypothetical contexts. Two studies were on bus-based PNRs, two studies were on rail-based PNRs, and four studies were on both bus-based and rail-based PNRs.

Key findings from the demand model studies are described here. Four studies were on mode choice models (Cornejo et al., 2014; Fan et al., 2016; Karamychev \& van Reeven, 2011; Zhang, 2014), two studies were on station choice models (Pang \& Khani, 2018; Webb \& Khani, 2020), and one study was 
on preferred choice of scenarios (Cao \& Duncan, 2019). The number of boardings was predicted by one study (Niles \& Pogodzinski, 2016). In the mode choice models, demography, land use, road density information, VKT, and VHD were used for predicting PNRs as a mode choice. In the station choice models, travel time and trip-related information were used to predict PNR station choices by commuters. The studies used discrete choice models as their methods, such as binary logit (Cornejo et al., 2014), mixed logit (Pang \& Khani, 2018), MNL (Cao \& Duncan, 2019; Fan et al., 2016; Karamychev \& van Reeven, 2011; Zhang, 2014), nested logit (NL) (Webb \& Khani, 2020), and Poisson regression models (Niles \& Pogodzinski, 2016).

Some strengths and weaknesses of the Demand Models studies are identified here, which again help to identify research gaps. A strength of the Demand Models studies is that the models can be developed with different types of revealed preference data, including travel surveys and transit fare card data. The models may be applicable to similar geographic areas. A weakness of these studies is that data from stated preference surveys to develop these models might be subject to various biases because of the hypothetical nature of the questions. Another noteworthy weakness is that emerging micromobility modes like shared bicycles and scooters are typically not considered in these models.

Many gaps are identified. First, the studies of the Demand Models use onboard surveys or household questionnaire surveys for data collection that lead to issues like limited sample sizes, missing information like parking cost and departure time data, and other biases. The models can potentially use alternative data collection methods like GPS traces, transit fare card data (Pang \& Khani, 2018), and electronic surveys in future research. Second, the existing Demand Models consider the association between mode/station choice and various demographic, geographic, and trip-related features. But many other factors have the potential to affect mode choice. Future research can investigate some of the factors, which include street network data like speed limits, congestion, the monetary cost associated with other modes, multiple transit paths (Webb \& Khani, 2020), payment information of the respondents, and transfer time between modes. Third, it was observed that machine learning algorithms have recently been introduced in the literature on travel mode choice; therefore, the application of machine learning techniques can be explored in predicting PNR demand.

\subsection{Theme 4: Network equilibrium and optimization}

A summary of the most relevant studies that worked with Network Equilibrium and Optimization of PNR locations and fees is provided in Table 4, and they are organized chronologically. As shown in Table 4, 12 studies were reviewed, among which nine were journal articles (Aros-Vera et al., 2013; Chen \& Kim, 2018; Holguin et al., 2012; Hou et al., 2020; Liu et al., 2018; Lu \& Guo, 2015; Song et al., 2017; Wang et al., 2014; Wang et al., 2015) and three were conference papers (Chen et al., 2017; Fan et al., 2016; Islam et al., 2015). Three papers were conducted in US cities (Aros-Vera et al., 2013; Holguin et al., 2012; Lu \& Guo, 2015) and nine studies were on hypothetical locations. Two studies were on rail-based and bus-based PNRs (Hou et al., 2020; Lu \& Guo, 2015) and the rest of the studies were on rail-based PNRs.

The key findings of these studies are described here. The studies reported that optimally located PNRs have the ability to influence riders to shift from automobiles to public transit. However, their optimal location, number, size, and parking fee depend on the objective functions and constraints considered in these PNR network design problems or models. The types and numbers of objective functions and constraints differ based on the goals of these studies. Some common objective functions in these studies were minimization of total travel cost, total travel time, VKT, VHD, budget, and parking construction costs, as well as maximization of PNR users. In some cases, more than one objective was considered, and a bi-objective programming (BP) model was used to deal with conflicting objectives. 
Constraints varied across studies, but parking space or PNR capacity constraints were common in some studies. Other types of constraints considered were equilibrium constraints (EC), complimentary constraints (CC), demand and flow conservation, equity constraints, and reliability constraints.

The network equilibrium approach to achieve optimal PNR locations typically had two levels in their analysis: a) logit models for modal split and b) different user equilibrium (UE) models for route choice in the network. Some studies considered PNRs as an independent mode and used MNL as their logit model and UE models for the route choice (Fan et al., 2016; Wang et al., 2015). In contrast, some studies considered PNRs to have qualities of both cars and transit, and these studies used more sophisticated logit models such as Cross Nested Logit Model (CNL) (Chen et al., 2017) and Nested Logit (NL) (Hou et al., 2020). Additional models like Combined Modal Split and Traffic Assignment (CMSTA) (Chen \& Kim, 2018; Hou et al., 2020; Liu et al., 2018), Mathematical Program with Complementary Constraints (MPCC) (Song et al., 2017), Mathematical Programming Model with Equilibrium Constraints (MPEC) (Liu et al., 2018), and Nonlinear Complementary Problem (NCP) (Islam et al., 2015) used various algorithms to solve the optimization problem. The solution algorithms commonly observed in these studies were Genetic Algorithm (GA) (Hou et al., 2020; Islam et al., 2015), Active Set Algorithm (ASA) (Song et al., 2017), Variational Inequality (VI) (Chen et al., 2017), and Self-Adaptive Gradient Projection (SAGP) algorithm (Chen \& Kim, 2018). Besides these linear and non-linear mathematical programs, there were some other approaches to find optimal PNR locations, such as the p-Hub and the Break Even Distance (BED) approaches. The former was a mixed linear program formulation that considered PNRs as hubs (Aros-Vera et al., 2013), and the latter was used to define catchment areas of PNRs (Holguin et al., 2012). Readers who are unfamiliar with these network equilibrium and optimization models are referred to the textbook "Urban Transportation Networks" by Sheffi (Sheffi, 1985).

Some strengths, weaknesses, and research gaps for the Network Equilibrium and Optimization studies are identified here. One strength of the Network Equilibrium and Optimization studies is their ability to build models based on hypothetical scenarios, which gives these studies the freedom to find optimal locations of PNRs. However, a weakness is difficulty applying these models in real world settings due to data unavailability and complexities of the road network. Although there are a limited number of real world examples, the geographic context is mostly limited to larger cities with big transit systems. Another weakness is that with the inclusion of each constraint and objective, the models give different optimal locations for PNRs. Hence, the selection of objectives and constraints are crucial.

Numerous areas for future research in the field of Network Equilibrium and Optimization are revealed from this review. First, past studies heavily focused on optimizing PNR locations for automobiles. Future studies can be attempted to identify optimal PNR locations for electric vehicles (EVs), as was done in a recent study in Beijing, China (Zhang et al., 2019). Second, most of the studies have implemented their models in hypothetical scenarios. Future studies can extend these models to capture the complexities of real-world networks. Third, issues like transit crowding effects, commuter heterogeneity (Wang et al., 2014), spatial equity (Lu \& Guo, 2015), congestion prices (Song et al., 2017), and various types of environmental pollutants (Chen \& Kim, 2018) can impact PNR locations and usage. Hence, they should be studied further.

Lastly, a relatively new concept is the "remote PNR," which refers to PNRs that are located at remote or low density suburban areas where riders typically arrive by automobile and then are carried to a rail station by a feeder bus service. More research on vulnerability, network capacity, and flexibility analysis (Liu et al., 2018) should be conducted for remote PNRs.

\subsection{Theme 5: Parking utilization}

A summary of the studies pertaining to the theme of Parking Utilization of PNRs is provided in Table 5. 
As shown in Table 5, there were three studies on this theme. There was one report (Gayah, Stieffenhofer, \& Shankar, 2014) and two journal articles (Stieffenhofer, Barton, \& Gayah V, 2016; Zhao, Chen, Jiao, Chen, \& Bischak, 2019). All three studies were on US counties or regions. Only one study was on busbased PNRs (Zhao et al., 2019) and two studies were on both rail-based and bus-based PNRs.

The key findings from the studies are described here. The studies reported that parking space utilization is impacted by parking fees. Lower or no parking fees were more desirable than higher parking fees by PNR users. PNR users were willing to walk 10-15 minutes for an ensured parking spot and pay fees higher than general parking fees of PNRs. Parking Utilization was found to be lower for a higher percentage of the driving population near PNR lots in one study (Zhao et al., 2019). Another two studies found that PNRs were mostly used by SOVs and less by other modes (Gayah et al., 2014; Stieffenhofer et al., 2016).

Some strengths, weaknesses, and research gaps for the Parking Utilization studies are identified here. A strength of the Parking Utilization studies is that most of these studies are based on actual utilization rates of existing PNRs. Therefore, the study results are relevant for practitioners and can be applied immediately in many real world settings. A weakness of these studies is that they typically consider only car users and none examined parking utilization of bike racks or scooter parking. Although these studies are intended to help increase PNR usage by cars, the studies could also expand the scope of parking usage to other sustainable modes. Research in this theme is limited and can benefit from further study. For instance, PNR lot utilization rates can be tested for various parking fees and amenities through sensitivity analysis (Zhao et al., 2019) for different types of areas or cities. This will help agencies to understand the influence of city types on PNR utilization. Future research can examine if parking space shortages or over-utilization can impact PNR demand in the United States, similar to how it was conducted in an earlier PNR study in Australia (Huang et al., 2019). Studies can also simulate scenarios to observe the effect of autonomous vehicles (AV) on PNR utilization as AVs might change the demand for PNR lots as per prior studies (Zhao et al., 2019).

\subsection{Theme 6: Other}

A summary of studies under the Other theme on PNRs is provided in Table 6, and they are organized chronologically. As shown in Table 6, there were nine studies among which there were seven journal articles (Cao \& Duncan, 2019; Carlson \& Owen, 2019; Duncan \& Christensen, 2013; Duncan \& Cook, 2014; Holguín-Veras et al., 2012; Karamychev \& van Reeven, 2011; Mock \& Thill, 2015), one conference paper (Li et al., 2010), and one report (Niles \& Pogodzinski, 2016). Out of nine studies, one was based on a hypothetical context, and the rest were in real-world settings. Five studies were on rail-based PNRs (Cao \& Duncan, 2019; Carlson \& Owen, 2019; Duncan \& Christensen, 2013; Duncan \& Cook, 2014; Holguín-Veras et al., 2012), two studies were on rail-based and bus-based PNRs (Karamychev \& van Reeven, 2011; Mock \& Thill, 2015), and two studies were on bus-based PNRs (Li et al., 2010; Niles \& Pogodzinski, 2016).

Key findings of the studies are described here. Three studies found a positive impact of PNRs on traffic, social welfare (Karamychev \& van Reeven, 2011), VKT (Duncan \& Cook, 2014), and transit operations (Niles \& Pogodzinski, 2016). However, conflicting evidence was found in Charlotte, where replacing PNRs with moderately dense housing reduced VKT in five out of seven LYNX stations (Duncan \& Cook, 2014). PNRs were also evaluated based on economic analysis, transit professionals' priorities, job accessibility, travel time, and safety in some studies. Discrete choice models were used for the investigation by four studies, but five studies used different methods.

Numerous research gaps are identified from the review. For example, the association between residential self-selection and PNRs can be explored because PNRs are likely to influence commuters to stay 
in distant and auto-dependent suburbs. Comparison of VKT reduction induced by PNR based work and non-work trips can also be investigated because there is a chance that PNRs reduce the auto trip length of work trips, but at the same time can increase the auto trip length of non-work trips (Duncan \& Cook, 2014). None of the studies investigated the impact of transit agencies' characteristics on PNR's locations (Duncan \& Christensen, 2013), and this can be another interesting area for future research. A comparison of PNRs with different kinds of land uses apart from TODs can be examined (Mock \& Thill, 2015).

Table 1. Summary of the Comparative Studies theme studies

\begin{tabular}{|c|c|c|c|c|c|}
\hline Author, Year & Location & Data Collection & Mode & Method & Key Findings \\
\hline $\begin{array}{l}\text { (Martin \& } \\
\text { Hurrell, 2012) }\end{array}$ & $\begin{array}{l}\text { Bay Area, } \\
\text { California }\end{array}$ & $\begin{array}{l}\text { User Survey, Sample = } 11 \text { subur- } \\
\text { ban stations of BART }\end{array}$ & Rail & $\begin{array}{l}\text { Transit ridership } \\
\text { and cost of station } \\
\text { parking calcula- } \\
\text { tion }\end{array}$ & $\begin{array}{l}\text { (i) Surface parking was a better op- } \\
\text { tion than high rise TOD. } \\
\text { (ii) Surface parking was better than } \\
\text { structured parking if the land value } \\
\text { was less than } \$ 2 \mathrm{mi} / \text { acre. }\end{array}$ \\
\hline $\begin{array}{l}\text { (Truong \& } \\
\text { Marshall, } \\
\text { 2014) }\end{array}$ & $\begin{array}{l}\text { Denver, } \\
\text { Colorado }\end{array}$ & $\begin{array}{l}\text { Onboard survey on Regional } \\
\text { Transportation District (RTD) } \\
\text { riders. Sample }=2019\end{array}$ & Rail & $\begin{array}{l}\text { Vehicle mileage } \\
\text { calculation, fuel } \\
\text { consumption, } \\
\text { the ratio of } \mathrm{CO}_{2} \\
\text { emission calcula- } \\
\text { tion }\end{array}$ & $\begin{array}{l}\text { (i) PNRs located in inner corridors } \\
\text { were less effective than end-of-line } \\
\text { PNR stations in reducing GHG } \\
\text { emissions. } \\
\text { (ii) Inner corridor PNRs caused } \\
\text { additional driving trips and SOV } \\
\text { transit access car trips. }\end{array}$ \\
\hline (Zhang, 2014) & Delaware & $\begin{array}{l}\text { Train Demand Survey, 2010; Bus } \\
\text { Demand Survey, } 2013\end{array}$ & $\begin{array}{l}\text { Rail and } \\
\text { Bus }\end{array}$ & $\begin{array}{l}\text { Gravity and mode } \\
\text { choice model for } \\
\text { rail-based PNR, } \\
\text { Tobit model for } \\
\text { bus-based PNR }\end{array}$ & $\begin{array}{l}\text { (i) Rail-based PNRs generally have } \\
\text { one destination and bus-based } \\
\text { PNRs have multiple destinations. } \\
\text { (ii) Rail-based PNRs have higher } \\
\text { utilization rates than bus-based } \\
\text { PNRs in Delaware. }\end{array}$ \\
\hline $\begin{array}{l}\text { (Fan et al., } \\
\text { 2016) }\end{array}$ & Hypothetical & $\begin{array}{l}\text { Dataset is adapted from Burgess } \\
\text { (2008) paper (Burgess, 2008) }\end{array}$ & Rail & $\begin{array}{l}\text { Residential reloca- } \\
\text { tion model and } \\
\text { travel demand } \\
\text { model }\end{array}$ & $\begin{array}{l}\text { (i) Choose the option that increases } \\
\text { ridership and decreases VKT and } \\
\text { VHD. } \\
\text { (ii) With increasing parking space, } \\
\text { PNR is more effective in increas- } \\
\text { ing ridership and decreasing VKT/ } \\
\text { VHD than a TOD of the same land } \\
\text { use area. }\end{array}$ \\
\hline $\begin{array}{l}\text { (Palakurthy et } \\
\text { al., 2017) }\end{array}$ & $\begin{array}{l}\text { Denver, } \\
\text { Colorado }\end{array}$ & $\begin{array}{l}\text { Trip Generation Data } 2015 . \\
\text { Sample }=40 \text { PNRs of RTD }\end{array}$ & $\begin{array}{l}\text { Rail and } \\
\text { Bus }\end{array}$ & $\begin{array}{l}\text { PNR vehicle } \\
\text { accumulation cal- } \\
\text { culation, weighted } \\
\text { average peak hour, } \\
\text { and daily trip } \\
\text { generation rates/ } \\
\text { occupied space }\end{array}$ & $\begin{array}{l}\text { (i) Regional bus PNRs can use both } \\
\text { regression equations and weighted } \\
\text { average rates for trip generation } \\
\text { estimates. } \\
\text { (ii) Daily trip generation rate/oc- } \\
\text { cupied space for bus and rail as per } \\
\text { ITE was } 9.62 \text { and } 3.91 \text {, but as per } \\
\text { RTD was } 3.5 \text { and } 3.91 \text {, respectively. }\end{array}$ \\
\hline $\begin{array}{l}\text { (Duncan, } \\
\text { 2019) }\end{array}$ & $\begin{array}{l}\text { Charlotte, } \\
\text { North } \\
\text { Carolina }\end{array}$ & $\begin{array}{l}2009 \text { onboard passenger survey } \\
\text { (Sample=351); } 2008 \text { on-board } \\
\text { LYNX passenger survey (Sample = } \\
721) ; 2011 \text { daily LYNX boardings } \\
\text { (7 stations); Mecklenburg County } \\
\text { Property Database }\end{array}$ & Rail & VKT calculations & $\begin{array}{l}\text { (i) Farthest located }(11-13 \mathrm{~km}) \\
\text { PNR resulted in more VKT reduc- } \\
\text { tion than TOD. }\end{array}$ \\
\hline
\end{tabular}


Table 2. Summary of the Guidelines and Best Practices theme studies

\begin{tabular}{|c|c|c|c|c|}
\hline Author, Year & Document & Location & Method & Key Findings \\
\hline $\begin{array}{l}\text { (Coffel et al., } \\
\text { 2012) }\end{array}$ & $\begin{array}{l}\text { TCRP } \\
\text { Report }\end{array}$ & US & $\begin{array}{l}\text { Stakeholder Inter- } \\
\text { views, Literature } \\
\text { Review, Case } \\
\text { Study }\end{array}$ & $\begin{array}{l}\text { (i) PNRs can be } 10-15 \text { miles away from the city center for the } \\
\text { case of inner suburbs, } 15-25 \text { miles away for the case of outer } \\
\text { suburbs, and over } 25 \text { miles away for the case of exurbia. } \\
\text { (ii) Maximum size of lot (typical) }=900-1200 \text { spaces. } \\
\text { (iii) Parking space per acre }=125-135 \text {. } \\
\text { (iv) Maximum passenger accumulation/shelter }=80-150 \text { people. } \\
\text { (v) Desirable pedestrian walking distance }=1,200 \text { feet ( } \max \text { ), } 5^{\prime} \\
\text { walkway width (min). }\end{array}$ \\
\hline $\begin{array}{l}\text { (Cherrington, } \\
\text { Brooks, Cardenas, } \\
\text { Elgart, Galicia, } \\
\text { Hansen, et al., } \\
\text { 2017) }\end{array}$ & $\begin{array}{l}\text { TCRP } \\
\text { Report }\end{array}$ & US & $\begin{array}{l}\text { Literature Review, } \\
\text { Industry Scan, } \\
\text { Case Study }\end{array}$ & $\begin{array}{l}\text { (i) PNRs should be located along good highways with transit } \\
\text { access and visibility, strong ridership potential, and a perception } \\
\text { of security. } \\
\text { (ii) Incorporating community input also helps in successful } \\
\text { PNRs. }\end{array}$ \\
\hline $\begin{array}{l}\text { (Cherrington, } \\
\text { Brooks, Cardenas, } \\
\text { Elgart, Galicia, } \\
\text { Hansen, Miller, et } \\
\text { al., 2017) }\end{array}$ & $\begin{array}{l}\text { TCRP } \\
\text { Report }\end{array}$ & US & $\begin{array}{l}\text { Literature Review, } \\
\text { Industry Scan, } \\
\text { Case Study }\end{array}$ & $\begin{array}{l}\text { (i) Transit agency-specific Demand Models are: } \\
\text { 1. Milwaukee (Portland, Oregon) PNR estimates developed by } \\
\text { TriMet (2011). } \\
\text { 2. Regional peer site model for Fort Bend County (Texas) Public } \\
\text { Transportation developed by TTI (2012). } \\
\text { 3. Access policy methodology developed by Bay Area Rapid } \\
\text { Transit (BART) (2005). }\end{array}$ \\
\hline (AECOM, 2012) & $\begin{array}{l}\text { State DOT } \\
\text { Guidelines }\end{array}$ & Florida & NA & $\begin{array}{l}\text { (i) Properties of PNRs are external features, internal lots, and } \\
\text { transit services. } \\
\text { (ii) The priority of closeness to transfer terminal: (1) bicycle } \\
\text { parking, (2) accessible parking, (3) kiss-and-ride and other drop- } \\
\text { offs/pickup areas, (4) short-term parking, (5) long term parking. } \\
\text { (iii) Automobile parking layout: 9' x 18.5', 90-degree standard } \\
\text { or } 8 \text { 'x 16', 90-degree compact dimensions. Both right angle and } \\
\text { angled parking are allowed. } \\
\text { (iv) Signage and marking should be Manual on Uniform Traffic } \\
\text { Control Devices (MUTCD) compliant. }\end{array}$ \\
\hline (VDOT, 2018) & $\begin{array}{l}\text { State DOT } \\
\text { Guidelines }\end{array}$ & Virginia & NA & $\begin{array}{l}\text { (i) Specification of PNRs in high-density areas: Reside in mul- } \\
\text { timodal suburban or urban areas. } 90^{\circ} \text { parking. } 8^{\prime} \mathrm{X} 20^{\prime} \text { kiss-and- } \\
\text { ride areas. } 50^{\prime} \text { or } 70^{\prime} \text { long bus boarding areas. } 1 \text { bicycle parking } \\
\text { for every } 10-20 \text { vehicle spaces with } 2 \text { point locking capability. } \\
\text { LED lights. } \\
\text { (ii) Specification of PNRs in medium density areas: Reside near } \\
\text { interchanges or suburban areas. Parking requirements similar to } \\
\text { high-density areas. No kiss-and-ride area. Bike parking with a } \\
\text { minimum of } 2-3 \text { racks. LED lighting. } \\
\text { (iii) Specification of PNRs in rural areas: Reside near interstates } \\
\text { or arterial roadways. } 45^{\circ} \text { or } 60^{\circ} \text { angle parking. } 50^{\prime} \text { to } 70^{\prime} \text { long } \\
\text { bus boarding areas. } 15^{\prime} \text { parking aisles for lots with one-way traf- } \\
\text { fic and } 60^{\circ} \text { parking. }\end{array}$ \\
\hline $\begin{array}{l}\text { (Mock \& Thill, } \\
\text { 2015) }\end{array}$ & $\begin{array}{l}\text { Journal } \\
\text { Article }\end{array}$ & US & $\begin{array}{l}\text { Interviews and } \\
\text { surveys of } 145 \\
\text { transit profes- } \\
\text { sionals }\end{array}$ & $\begin{array}{l}\text { (i) Transit planners consider capital cost as a crucial factor in } \\
\text { determining which rapid transit station should have PNRs. } \\
\text { (ii) Transit agency managers of large cities prefer PNR demand } \\
\text { over land use considerations, in contrast to planners and } \\
\text { engineers, but those of mid-tier cities prefer land use over PNR } \\
\text { demand. } \\
\text { (iii) For locating PNRs in larger cities, transit planners prioritize } \\
\text { proximity to residential areas and relationship to primary activ- } \\
\text { ity center or CBD over proximity to highways or congested } \\
\text { thoroughfares, but the priorities swap in mid-tier cities. }\end{array}$ \\
\hline
\end{tabular}


Table 3. Summary of the Demand Models theme studies

\begin{tabular}{|c|c|c|c|c|c|c|}
\hline Author, Year & Location & $\begin{array}{l}\text { Data Collec- } \\
\text { tion }\end{array}$ & Mode & Model & $\begin{array}{l}\text { Dependent } \\
\text { Variable }\end{array}$ & Key Findings \\
\hline $\begin{array}{l}\text { (Karamychev } \\
\text { \& van Reeven, } \\
2011)\end{array}$ & Hypothetical & NA & $\begin{array}{l}\text { Rail and } \\
\text { Bus }\end{array}$ & MNL & $\begin{array}{l}\text { Choice set of } \\
\text { modes (Auto, } \\
\text { Transit, and } \\
\text { PNR) }\end{array}$ & $\begin{array}{l}\text { (i) Remote PNRs can reduce traffic } \\
\text { if more car users prefer to use these } \\
\text { PNRs. } \\
\text { (ii) Remote PNRs are attractive for } \\
\text { both car and transit users when con- } \\
\text { gestion and parking at the city center } \\
\text { is considered. }\end{array}$ \\
\hline $\begin{array}{l}\text { (Cornejo et } \\
\text { al., 2014) }\end{array}$ & $\begin{array}{l}\text { El Paso, } \\
\text { Texas, USA }\end{array}$ & $\begin{array}{l}\text { Survey, } 447 \mathrm{El} \\
\text { Paso residents }\end{array}$ & Bus & Binary Logit & $\begin{array}{l}\text { Choice set } \\
\text { of modes } \\
\text { (PNR or other } \\
\text { modes) }\end{array}$ & $\begin{array}{l}\text { (i) PNR utilization rates are positively } \\
\text { associated with: road density, employ- } \\
\text { ment density and percentages of } \\
\text { people between } 18-34 \text { and } 65+\text {. }\end{array}$ \\
\hline (Zhang, 2014) & $\begin{array}{l}\text { Delaware, } \\
\text { USA }\end{array}$ & $\begin{array}{l}\text { Train Demand } \\
\text { Survey, 2010; } \\
\text { Bus Demand } \\
\text { Survey, } 2013 \text {. }\end{array}$ & $\begin{array}{l}\text { Rail and } \\
\text { Bus }\end{array}$ & MNL, Tobit & $\begin{array}{l}\text { Choice set of } \\
\text { modes (PNR } \\
\text { or Auto) }\end{array}$ & $\begin{array}{l}\text { (i) Tobit is a better model for predict- } \\
\text { ing bus-based PNR demand than } \\
\text { MNL model. } \\
\text { (ii) MNL model can be combined } \\
\text { with gravity model to estimate rail- } \\
\text { based PNR demand. }\end{array}$ \\
\hline $\begin{array}{l}\text { (Fan et al., } \\
\text { 2016) }\end{array}$ & Hypothetical & $\begin{array}{l}\text { Dataset is } \\
\text { adapted from } \\
\text { Burgess (2008) } \\
\text { paper (Burgess, } \\
\text { 2008) }\end{array}$ & Rail & $\begin{array}{l}\text { Four step travel } \\
\text { demand model } \\
\text { with residential } \\
\text { relocation } \\
\text { model }\end{array}$ & $\begin{array}{l}\text { Choice set of } \\
\text { modes (Auto, } \\
\text { metro, and } \\
\text { PNR) }\end{array}$ & $\begin{array}{l}\text { (i) Travel demand changes signifi- } \\
\text { cantly (ridership increases and VKT/ } \\
\text { VHD reduces significantly) when a } \\
\text { new PNR or TOD is developed. } \\
\text { (ii) Travel demand reduces when exist- } \\
\text { ing PNR is replaced with a limited } \\
\text { scale TOD. }\end{array}$ \\
\hline $\begin{array}{l}\text { (Niles \& } \\
\text { Pogodzinski, } \\
\text { 2016) }\end{array}$ & $\begin{array}{l}\text { The western } \\
\text { USA }\end{array}$ & $\begin{array}{l}\text { American } \\
\text { Community } \\
\text { Survey, 2010; } \\
\text { Transit agencies }\end{array}$ & Bus & $\begin{array}{l}\text { OLS and Pois- } \\
\text { son Regression }\end{array}$ & $\begin{array}{l}\text { Boarding, } \\
\text { Boardings per } \\
\text { trip }\end{array}$ & $\begin{array}{l}\text { (i) Transit ridership can be influenced } \\
\text { more by PNRs than residential hous- } \\
\text { ing. }\end{array}$ \\
\hline $\begin{array}{l}\text { (Pang \& } \\
\text { Khani, 2018) }\end{array}$ & $\begin{array}{l}\text { Austin, } \\
\text { Texas, USA }\end{array}$ & $\begin{array}{l}\text { Onboard survey } \\
\text { by CapMetro, } \\
418 \text { riders }\end{array}$ & $\begin{array}{l}\text { Rail and } \\
\text { Bus }\end{array}$ & $\begin{array}{l}\text { Logit, Logit } \\
\text { with interac- } \\
\text { tion terms, } \\
\text { Mixed Logit, } \\
\text { Mixed Logit } \\
\text { with correla- } \\
\text { tion }\end{array}$ & $\begin{array}{l}\text { Choice set of } \\
\text { PNRs }\end{array}$ & $\begin{array}{l}\text { (i) Travelers prefer shorter auto travel } \\
\text { time from the origin to the PNR, } \\
\text { transit in-vehicle-time greater than } 10 \\
\text { minutes, and fewer transfers during } \\
\text { transit trips. }\end{array}$ \\
\hline $\begin{array}{l}\text { (Cao \& Dun- } \\
\text { can, 2019) }\end{array}$ & $\begin{array}{l}\text { Twin Cities, } \\
\text { Minnesota }\end{array}$ & $\begin{array}{l}\text { Online Survey, } \\
570 \text { riders }\end{array}$ & Rail & MNL & $\begin{array}{l}\text { Is the scenario } \\
\text { a preferred } \\
\text { choice? (Yes/ } \\
\text { No) }\end{array}$ & $\begin{array}{l}\text { (i) Influence of walking distance is } \\
\text { stronger than intersection safety, } \\
\text { pedestrian infrastructure, and building } \\
\text { appearance on PNR user choices. }\end{array}$ \\
\hline $\begin{array}{l}\text { (Webb \& } \\
\text { Khani, 2020) }\end{array}$ & $\begin{array}{l}\text { Twin Cities, } \\
\text { Minnesota, } \\
\text { USA }\end{array}$ & $\begin{array}{l}\text { Onboard survey } \\
\text { by Metro Tran- } \\
\text { sit, } 1690 \text { users }\end{array}$ & $\begin{array}{l}\text { Rail and } \\
\text { Bus }\end{array}$ & $\begin{array}{l}\text { MNL, Nested } \\
\text { Logit, Mixed } \\
\text { Logit }\end{array}$ & $\begin{array}{l}\text { Choice set of } \\
\text { PNRs }\end{array}$ & $\begin{array}{l}\text { (i) Riders preferred those PNRs that } \\
\text { had a small distance ratio. } \\
\text { (ii) Distance ratio indicates how "out } \\
\text { of the way" PNR is when direc- } \\
\text { tion from origin to destination is } \\
\text { considered. }\end{array}$ \\
\hline
\end{tabular}


Table 4. Summary of the Network Equilibrium and Optimization theme studies

\begin{tabular}{|c|c|c|c|c|}
\hline Author, Year & Location & Mode & Method & Key Findings \\
\hline (Wang et al., 2014) & Hypothetical & Rail & DUE & $\begin{array}{l}\text { (i) PNR parking fee scheme can be used to improve the } \\
\text { network travel efficiency with the second-best road pricing. }\end{array}$ \\
\hline (Wang et al., 2015) & Hypothetical & Rail & UE & $\begin{array}{l}\text { (i) Total travel cost decreased with an increasing number of } \\
\text { parking spots at destination. }\end{array}$ \\
\hline $\begin{array}{l}\text { (Holguin et al., } \\
\text { 2012) }\end{array}$ & $\begin{array}{l}\text { Manhattan } \\
\text { New York }\end{array}$ & Rail & BED & $\begin{array}{l}\text { (i) Location of PNR depends on Transit LOS. } \\
\text { (ii) PNR catchment area had a parabolic shape. } \\
\text { (iii) Better transit LOS provides larger catchment areas. }\end{array}$ \\
\hline $\begin{array}{l}\text { (Aros-Vera et al., } \\
\text { 2013) }\end{array}$ & $\begin{array}{l}\text { Queens, New } \\
\text { York }\end{array}$ & Rail & p-Hub & $\begin{array}{l}\text { (i) Five best locations were identified from } 21 \text { candidate } \\
\text { PNRs. } \\
\text { (ii) Demand derived by the p-Hub approach was lower than } \\
\text { that of Holguin-Veras et al. (2012) model. }\end{array}$ \\
\hline (Lu \& Guo, 2015) & $\begin{array}{l}\text { Anaheim, } \\
\text { California }\end{array}$ & $\begin{array}{l}\text { Rail \& } \\
\text { Bus }\end{array}$ & $\mathrm{BP}$ & $\begin{array}{l}\text { (i) Passenger Flow Volume per Cost (PFVC) is regarded as } \\
\text { an index for the level of the rate of investment return. }\end{array}$ \\
\hline (Islam et al., 2015) & Hypothetical & Rail & NCP, GA & $\begin{array}{l}\text { (i) The value of network reliability in the worst PNR sce- } \\
\text { nario was higher than the no PNR scenario. }\end{array}$ \\
\hline (Fan et al., 2016) & Hypothetical & Rail & UE & $\begin{array}{l}\text { (i) TOD density beyond the equilibrium point can cause } \\
\text { higher investment costs and attract less residents. }\end{array}$ \\
\hline (Song et al., 2017) & Hypothetical & Rail & MPCC, ASA & $\begin{array}{l}\text { (i) Optimal design reduces the social cost by } 32.59 \% \text { from } \\
\text { status quo conditions. } \\
\text { (ii) It also encourages riders to shift from automobile to } \\
\text { transit and PNRs. }\end{array}$ \\
\hline (Chen et al., 2017) & Hypothetical & Rail & CNL, UE, VI & $\begin{array}{l}\text { (i) CNL and UE model with mean-excess stochastic travel } \\
\text { times influenced the mode choice and route choice pattern. }\end{array}$ \\
\hline (Chen \& Kim, 2018) & Hypothetical & Rail & $\begin{array}{l}\text { EC-CMSTA, } \\
\text { SAGP }\end{array}$ & $\begin{array}{l}\text { (i) By lowering the environmental protection threshold, } \\
\text { auto usage can be reduced and more travelers will shift to } \\
\text { transit. }\end{array}$ \\
\hline (Liu et al., 2018) & Hypothetical & Rail & MPEC & $\begin{array}{l}\text { (i) The remote PNR scheme effectively mitigates conges- } \\
\text { tion. } \\
\text { (ii) Multimodal expected total travel time (METTT) im- } \\
\text { proves with budget increases until budget reaches a suitable } \\
\text { level. }\end{array}$ \\
\hline (Hou et al., 2020) & Hypothetical & $\begin{array}{l}\text { Rail \& } \\
\text { Bus }\end{array}$ & $\begin{array}{l}\text { CMSTA (NL-UE), } \\
\text { GA }\end{array}$ & $\begin{array}{l}\text { (i) Optimally located remote PNRs influence network users } \\
\text { to use public transit. } \\
\text { (ii) Optimally located PNRs also improve social benefits. }\end{array}$ \\
\hline
\end{tabular}


Table 5. Summary of the Parking Utilization theme studies

\begin{tabular}{|c|c|c|c|c|c|}
\hline Author, Year & Location & Data Collection & Mode & Method & Key Findings \\
\hline $\begin{array}{l}\text { (Gayah et al., } \\
\text { 2014) }\end{array}$ & $\begin{array}{l}\text { Central Puget } \\
\text { Sound Region, } \\
\text { Seattle, Wash- } \\
\text { ington }\end{array}$ & $\begin{array}{l}\text { On-site audit (10 PNR } \\
\text { lots), intercept and elec- } \\
\text { tronic survey (17 PNR } \\
\text { Lots), sample = } 3341\end{array}$ & $\begin{array}{l}\text { Rail and } \\
\text { Bus }\end{array}$ & $\begin{array}{l}\text { Calculate person } \\
\text { occupancy of } \\
\text { parked vehicles, } \\
\text { analysis of users' } \\
\text { opinions }\end{array}$ & $\begin{array}{l}\text { (i) Person occupancy of parked } \\
\text { vehicles for all PNRs was about } 1 \text {, } \\
\text { meaning the majority of PNR users } \\
\text { arrive by SOVs. } \\
\text { (ii) PNR users are willing to pay } \$ 1.5 \\
\text { as a general parking fee, } \$ 1.83 \text { for an } \\
\text { ensured parking spot, and } \$ 1.53 \text { on } \\
\text { average for an ensured space that is } \\
10-15 \text { minutes walking distance away } \\
\text { from the PNR. } \\
\text { (iii) } 100 \% \text { of parking space at } 7 \text { out } \\
\text { of } 10 \text { PNRs were filled before } 9 \text { am. }\end{array}$ \\
\hline $\begin{array}{l}\text { (Stieffenhofer et } \\
\text { al., 2016) }\end{array}$ & $\begin{array}{l}\text { Central Puget } \\
\text { Sound Region, } \\
\text { Seattle, Wash- } \\
\text { ington }\end{array}$ & $\begin{array}{l}\text { On-site audit (9 PNR } \\
\text { lots), intercept and elec- } \\
\text { tronic survey (17 PNR } \\
\text { Lots), sample = } 3341\end{array}$ & $\begin{array}{l}\text { Rail and } \\
\text { Bus }\end{array}$ & $\begin{array}{l}\text { Person efficiency, } \\
\text { analysis of users' } \\
\text { opinions }\end{array}$ & $\begin{array}{l}\text { (i) Person efficiency is a more } \\
\text { straight- forward method compared } \\
\text { to person occupancy of parked } \\
\text { vehicles. } \\
\text { (ii) Person efficiency values for all } \\
\text { PNRs were about } 1 .\end{array}$ \\
\hline $\begin{array}{l}\text { (Zhao et al., } \\
\text { 2019) }\end{array}$ & $\begin{array}{l}\text { King County, } \\
\text { Washington }\end{array}$ & $\begin{array}{l}\text { Data from } 2004 \text { - } 2017 . \\
\text { Source: King County } \\
\text { Metro Transit, King } \\
\text { County GIS Open Data, } \\
\text { Puget Sound Regional } \\
\text { Council, American } \\
\text { Community Survey, } \\
\text { US Energy Information } \\
\text { Administration }\end{array}$ & Bus & Tobit Model & $\begin{array}{l}\text { (i) There is a positive association } \\
\text { between the utilization rate of PNRs } \\
\text { and transit ridership, road density, } \\
\text { employment density, mixed land } \\
\text { uses, percentages of people aged be- } \\
\text { tween } 18 \text { and } 34 \text { and people over } 65 \text {, } \\
\text { the percentage of Caucasians, and the } \\
\text { percentage of low-income people. } \\
\text { (ii) Transit ridership within a } 0.25- \\
\text { mile buffer is positively associated } \\
\text { with the utilization rate of PNR lots. }\end{array}$ \\
\hline
\end{tabular}


Table 6. Summary of Other theme studies

\begin{tabular}{|c|c|c|c|c|}
\hline Author, Year & Location & Mode & Method & Key Findings \\
\hline $\begin{array}{l}\text { (Karamychev \& van } \\
\text { Reeven, 2011) }\end{array}$ & Hypothetical & Rail and Bus & MNL & $\begin{array}{l}\text { (i) Remote PNRs can reduce traffic } \\
\text { if more car users prefer to use these } \\
\text { PNRs. } \\
\text { (ii) PNRs can increase social welfare if } \\
\text { traffic moves toward the periphery. }\end{array}$ \\
\hline (Li et al., 2010) & South Bay, CA & Bus & $\begin{array}{l}\text { Time-dependent } \\
\text { shortest path and } \mathrm{K} \\
\text { shortest path algo- } \\
\text { rithm }\end{array}$ & $\begin{array}{l}\text { (i) Preliminary case studies resulted in } \\
\text { satisfactory performance by the trip } \\
\text { planning system. }\end{array}$ \\
\hline $\begin{array}{l}\text { (Holguín-Veras et al., } \\
\text { 2012) }\end{array}$ & New York & Rail & Economic analysis & $\begin{array}{l}\text { (i) Present value of benefits of each } \\
\text { of the top } 20 \text { candidates were }>\$ 44 \\
\text { million. } \\
\text { (ii) Top five PNRs had a weighted } \\
\text { average savings of } \$ 12 / \text { user/day. }\end{array}$ \\
\hline $\begin{array}{l}\text { (Duncan \& Chris- } \\
\text { tensen, 2013) }\end{array}$ & USA & Rail & $\begin{array}{l}\text { Binary Logit Model } \\
\text { (Will the LRT station } \\
\text { have PNR? Yes=1, } \\
\text { No=0) }\end{array}$ & $\begin{array}{l}\text { (i) PNRs of LRT stations are more } \\
\text { likely to be found in less urban places } \\
\text { where land is cheaper and density is } \\
\text { lower, and in politicized municipal } \\
\text { environments. }\end{array}$ \\
\hline $\begin{array}{l}\text { (Duncan \& Cook, } \\
\text { 2014) }\end{array}$ & Charlotte, NC & Rail & VKT calculation & $\begin{array}{l}\text { (i) PNRs replaced by moderately } \\
\text { dense housing having } 50-100 \text { units/ } \\
\text { hectare reduced VKT for five out of } \\
\text { seven LYNX stations. }\end{array}$ \\
\hline $\begin{array}{l}\text { (Mock \& Thill, } \\
\text { 2015) }\end{array}$ & USA & Rail and Bus & $\begin{array}{l}\text { Ranking PNRs place- } \\
\text { ment factors with a } \\
\text { 4-point Likert scale }\end{array}$ & $\begin{array}{l}\text { (i) To place PNRs in mid-tier cities, } \\
\text { transit planners prioritized conve- } \\
\text { nience over economics, but the priori- } \\
\text { ties swap in larger cities. }\end{array}$ \\
\hline $\begin{array}{l}\text { (Niles \& Pogodzin- } \\
\text { ski, 2016) }\end{array}$ & The western USA & Bus & $\begin{array}{l}\text { OLS and Poisson Re- } \\
\text { gression; Route-level } \\
\text { \& Stop-level analysis }\end{array}$ & $\begin{array}{l}\text { (i) Productivity of bus operations } \\
\text { can increase by expanding parking in } \\
\text { suburban PNRs. }\end{array}$ \\
\hline $\begin{array}{l}\text { (Carlson \& Owen, } \\
\text { 2019) }\end{array}$ & $\begin{array}{l}\text { Twin Cities, Min- } \\
\text { nesota }\end{array}$ & Rail & $\begin{array}{l}\text { Calculation of Work- } \\
\text { er-Weighted Average } \\
\text { Job Accessibility }\end{array}$ & $\begin{array}{l}\text { (i) A } 30 \text {-minute PNR trip measure } \\
\text { increases average worker-weighted job } \\
\text { accessibility by } 230 \% \text { compared to a } \\
\text { walk-to-transit measure. }\end{array}$ \\
\hline $\begin{array}{l}\text { (Cao \& Duncan, } \\
\text { 2019) }\end{array}$ & $\begin{array}{l}\text { Twin Cities, Min- } \\
\text { nesota }\end{array}$ & Rail & MNL & $\begin{array}{l}\text { (i) PNR users are more likely to walk } \\
\text { an additional } 1.8 \text { blocks from a PNR } \\
\text { to the stop if they are provided with } \\
\text { better intersections and a welcoming } \\
\text { walking environment. }\end{array}$ \\
\hline
\end{tabular}

\section{$4 \quad$ Key findings}

Key findings from the literature review are briefly described here. This includes a high-level synthesis of the similarities and differences in the methodologies, geographic locations, and modes (bus versus rail) considered in the PNR studies discussed in the previous sections. Additionally, a brief discussion of the themes and their relationships is presented. 


\subsection{Methodologies}

There are some notable differences in the methodologies and findings of the publications on PNRs. Journal articles, conference papers, and thesis works often used various statistical modeling techniques to understand PNR systems. Overall, multinomial logit models (MNL) were the most widely used method in PNR studies. Numerous other regression models were used in the demand models theme, namely binary logit, mixed logit, nested logit, poisson, and ordinary least squares. The Parking Utilization theme used person occupancy and person efficiency calculations along with demand models as their methods. Various mathematical programming techniques and solution algorithms were used in the Network Equilibrium and Optimization theme based studies. Qualitative methods were more common in the Guidelines and Best Practices theme, including literature reviews, industry scans, and case studies.

\subsection{Geographic locations}

Figure 4 shows a map of the locations of PNR studies published in the last decade. It should be noted that the map does not include nationwide studies or studies with hypothetical locations. For instance, most TCRP reports are for the entire US and were therefore not shown in the figure. Similarly, many of the locations of Network Equilibrium and Optimization papers were hypothetical; hence these papers are not shown on the map. From this map, it can be concluded that the location of numerous PNR studies were in areas with extensive transit services, such as the San Francisco Bay Area, California; Twin Cities, Minnesota; New York City, New York; and Seattle and King County; Washington. It can also be concluded that there are few, if any, studies in more auto-dependent cities, such as those in the south, Midwest, and the Sun Belt regions. Therefore, future research should consider PNRs in more auto-dependent cities and/or regions of the US where there is lower transit ridership, less utilization of PNRs, or no PNRs. For example, Network Equilibrium and Optimization models could be applied to cities or regions that might benefit from development of new PNR systems. Last, states and regions that do not already have their own published PNR policy and design guidelines could consider developing one, like Florida and Virginia.

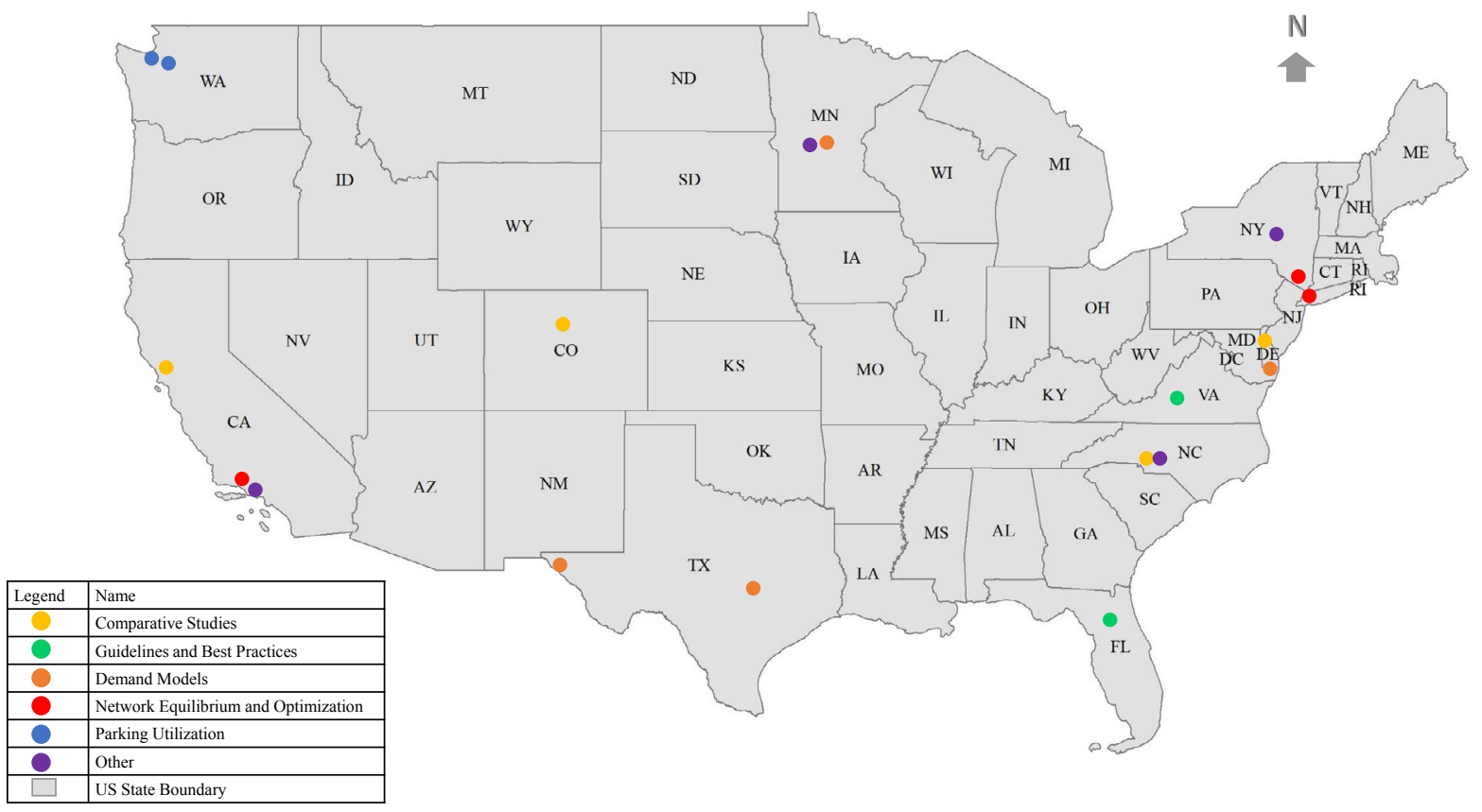

Figure 4. Map of locations of PNR studies in the US in the last ten years 
In addition to the geographic location of the studies themselves, there was a notable trend regarding the location of PNR facilities within many of the study areas. Specifically, numerous studies concluded that PNRs located near the edge of cities, in suburbs, or in more remote urban areas had advantageous properties such as the ability to increase transit ridership, influence riders to choose PNRs instead of automobiles, reduce VKT/VHD, and/or increase social welfare. PNRs located closer to the center city tended to experience fewer benefits; instead, these center city station locations performed better if they were developed as TODs. Similarly, some studies found that TODs were not as productive compared to PNR stations near the end of transit lines. This pattern suggests that there may be a relationship of PNR versus TOD depending on the location within urban areas, and it is shown visually in Figure 5.

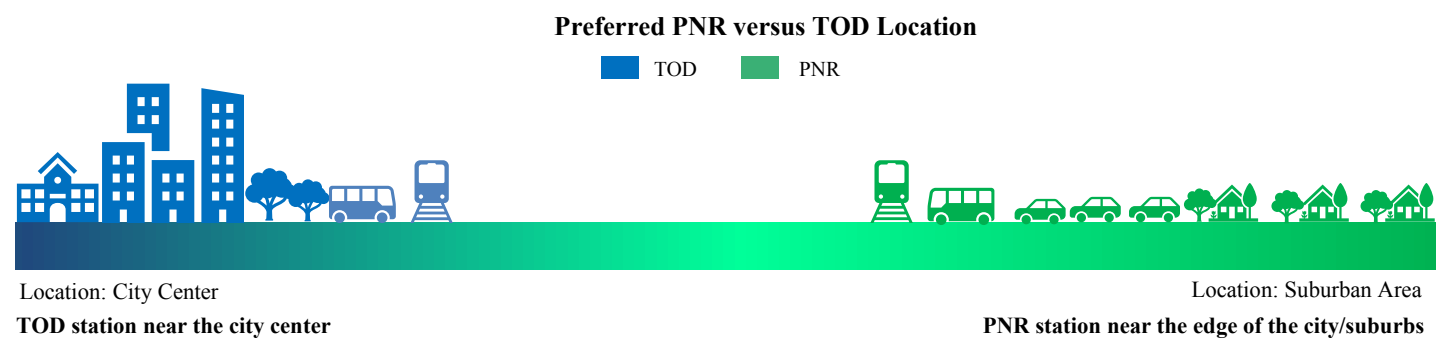

Figure 5. Preferred PNR versus TOD location

\subsection{Mode}

Figure 6 shows the frequency distribution of rail and bus PNR studies conducted in the last ten years in the US. As shown in the chart, the majority of studies were about rail PNRs (18 of 37 studies), followed by both bus and rail studies ( 15 of 37 studies). Only 4 of 37 studies examined bus-only PNRs. However, there are a relatively small number of American cities with rail systems and a much larger number of cities with bus services. This suggests that a valuable area for additional research on PNRs pertains to bus-based systems, which could have broad applicability in many US cities. Moreover, recent ridership trends in the US have shown significant declines in bus ridership; understanding how bus ridership declines can be reversed and people can be shifted from using cars to using the bus is an important topic for planners and policymakers. Bus-based PNR studies could potentially play a key role in such investigations. 


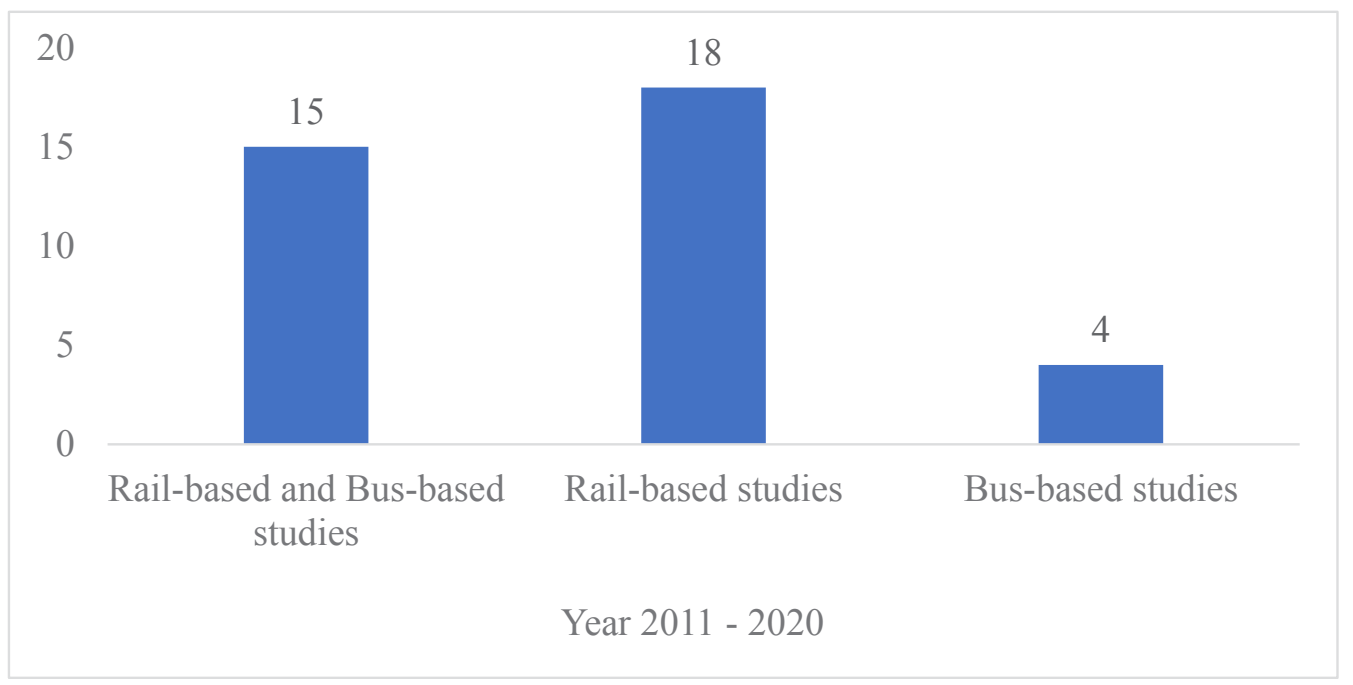

Figure 6. Distribution of bus-based PNR studies in the last ten years ( $\mathrm{n}=37$ studies)

\subsection{Relationships between the themes}

Although the six themes identified in this paper were discussed individually, the themes exhibit some noteworthy dependencies. For example, a dependency was identified if results of models in one theme were used as an input to studies in another theme. These relationships are summarized visually in Figure 7 , where the direction of the arrows indicates where the results or models are being used. As shown in the figure, it could be argued that all of the themes are considered dependent on the Guidelines and Best Practices theme because it contains key definitions and design guidelines to develop PNRs and conduct PNR-related analyses. All of the themes are also dependent on the Demand Models theme as they all use discrete models or demand calculations for their analysis. The Network Equilibrium and Optimization theme depends on the Demand Models theme since the demand estimates may be needed as an input for optimization modelling. The Comparative Studies theme includes studies of different PNRs or between PNRs and TODs and typically compared demand model estimates and/or parking utilization; hence, the Comparative Studies theme is also dependent on the Demand Models and the Parking Utilization themes.

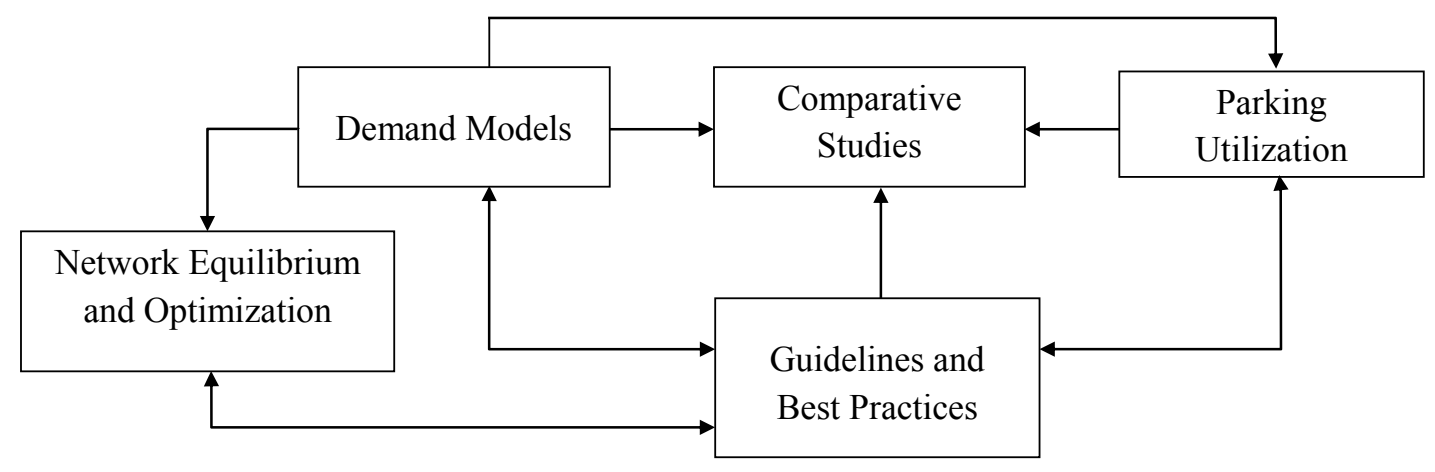

Figure 7. Relationships between the themes 


\section{$5 \quad$ Conclusions and future research}

This study presented a comprehensive review of recent literature on PNRs focusing on the United States. In total, 37 studies were collected and then categorized into six themes, namely Comparative Studies, Guidelines and Best Practices, Demand Models, Network Equilibrium and Optimization, Parking Utilization, and Other. Key findings and some areas for future research from each of the themes were as follows:

1. Comparative studies found that compared to TODs, PNRs reduced more VKT and VHD when when PNRs were in locations farther from the city center and near the end of transit lines. In the future, other trips should also be considered in the analysis to see which facility causes more VKT reductions other than work based trips. Comparison between PNRs and TODs for BRT or express bus services can be examined as many US cities that do not have rail services might wish to have bus-based PNRs to increase ridership.

2. Guidelines and Best Practices studies showed that despite having general guidelines for the entire US context from TCRP reports, state DOT PNR development guidelines varied across states. State DOT guidelines that were published on the internet were limited in number, and no research examined the efficacy of those guidelines.

3. Demand Model studies developed PNR demand models for their cities based on user surveys and travel time information. For future research, the association of mode choice with more street network data like speed limits, congestion, the monetary cost associated with other modes, multiple transit paths (Webb \& Khani, 2020), payment information of the respondents, and transfer time can be explored. Alternative data collection methods like GPS traces, transit fare card data (Pang \& Khani, 2018), and electronic surveys can be used to increase sample sizes.

4. Network Equilibrium and Optimization studies generally concluded that optimally located PNRs had the ability to influence riders to shift from automobiles to public transit. The optimal location might differ based on the objectives and constraints selected in the optimization model. The developed optimization models can be tested in more real-world settings in the future.

5. Parking Utilization theme found that parking fees play a vital role in parking space utilization. Lower or no parking fees were more desirable than paying higher parking fees by PNR users. The number of papers on this theme was also comparatively limited. Hence, this theme will benefit from further research.

6. Other studies analyzed PNRs from environmental, economic, and land-use perspectives. Studies under this theme were unique. Therefore, the scope for future research is also wide-ranging and open-ended for this theme.

This systematic literature review will help policymakers and urban planners to better plan and implement PNR networks in their cities. It will also help researchers to see the broad picture of recent trends in PNR research and address the gaps in the PNR literature.

\section{Acknowledgements}

The research was supported by the Tennessee Department of Transportation (TDOT) as part of the project titled "Improvement of Park-And-Ride Facilities and Services in Metropolitan Areas of Tennessee" (Grant No. RES 2020 -15). The authors would like to thank Dr. Ali Marie Boggs for her insights about text mining. The authors would also like to thank the UTK Writing Center and a Ph.D. student from the Civil Engineering Department of the University of Tennessee, Knoxville, for proofreading the paper. 


\section{References}

AECOM. (2012). State park-and-ride guide. Retrieved from https://fdotwww.blob.core.windows. net/sitefinity/docs/default-source/transit/documents/state-of-florida-park-and-ride-guide. pdf?sfvrsn=f947dc8_2

Aros-Vera, F., Marianov, V., \& Mitchell, J. E. (2013). p-Hub approach for the optimal park-and-ride facility location problem. European Journal of Operational Research, 226(2), 277-285.

Burgess, J. J. S. (2008). A comparative analysis of the park-and-rideltransit-oriented development tradeoff (doctoral dissertation). Massachusetts Institute of Technology, Cambridge, MA.

Cao, J., \& Duncan, M. (2019). Associations among distance, quality, and safety when walking from a park-and-ride facility to the transit station in the Twin Cities. Journal of Planning Education and Research, 39(4), 496-507.

Carlson, K., \& Owen, A. (2019). Accessibility impacts of park-and-ride systems. Transportation Research Record, 2673(9), 72-82.

Chen, X., \& Kim, I. (2018). Modelling rail-based park and ride with environmental constraints in a multimodal transport network. Journal of Advanced Transportation. https://doi. org/10.1155/2018/2310905

Chen, X., Liu, Z., Hua, D., \& Kim, I. (2017). A new model for rail-based park-and-ride with feeder bus services. Transportation Research Procedia, 21, 79-86.

Chen, X., Liu, Z., Islam, S., \& Deng, W. (2014). Park-and-ride network design in a bi-modal transport network to prompt public transport mode share. In M Beer, S.-K. Au, and J. W. Hall (Eds.), Vulnerability, uncertainty, and risk: Quantification, mitigation, and management (pp. 2282-2291), Proceedings of the Second International Conference on Vulnerability and Risk Analysis and Management (ICVRAM) and the Sixth International Symposium on Uncertainty Modeling and Analysis (ISUMA), Liverpool, UK. https://doi.org/10.1061/9780784413609

Cherrington, L. K., Brooks, J., Cardenas, J., Elgart, Z., Galicia, L. D., Hansen, T., ... Walk, M. J. (2017). Decision-making toolbox to plan and manage park-and-ride facilities for public transportation (TCRP Research Report 192). Washington DC: Transportation Research Board.

Cherrington, L. K., Brooks, J., Cardenas, J., Elgart, Z., Galicia, L. D., Hansen, T., Miller, ... Coffel, K. (2017). Decision-making toolbox to plan and manage park-and-ride facilities for public transportation: Research report and transit agency case studies (TCRP Web only Document 69). Washington DC: Transportation Research Board.

Coffel, K., Parks, J., Semler, C., Ryus, P., Sampson, D., Kachadoorian, C., Levinson, H. S., \& Schofer, J. L. (2012). Guidelines for providing access to public transportation stations (TCRP Report 153). Washington DC: Transportation Research Board.

Cornejo, L., Perez, S., Cheu, R. L., \& Hernandez, S. (2014). An approach to comprehensively evaluate potential park and ride facilities. International Journal of Transportation Science and Technology, 3(1), $1-18$.

Duncan, M. (2019). Would the replacement of park-and-ride facilities with transit-oriented development reduce vehicle kilometers traveled in an auto-oriented US region? Transport Policy, 81, 293301.

Duncan, M., \& Christensen, R. K. (2013). An analysis of park-and-ride provision at light rail stations across the US. Transport Policy, 25, 148-157.

Duncan, M., \& Cook, D. (2014). Is the provision of park-and-ride facilities at light rail stations an effective approach to reducing vehicle kilometers traveled in a US context? Transportation Research Part A: Policy and Practice, 66, 65-74. 
Fan, W., Jiang, X., \& Erdogan, S. (2016). Land-use policy for transit station areas: Park-and ride versus transit-oriented development. Paper presented at the 95th Annual Meeting of Transportation Research Board, Washington, DC.

Feldman, R., \& Dagan, I. (1995). Knowledge discovery in textual databases (KDT). Paper presented at the First International Conference on Knowledge Discovery and Data Mining (KDD-95), Montreal, Canada.

Gayah, V. V., Stieffenhofer, K., \& Shankar, V. (2014). How can we maximize efficiency and increase person occupancy at overcrowded park and rides? State College, PA: Mid-Atlantic Universities Transportation Center.

Holguín-Veras, J., Reilly, J., Aros-Vera, F., Yushimito, W., \& Isa, J. (2012). Park-and-ride facilities in New York City: Economic analyses of alternative locations. Transportation Research Record, 2276(1), 123-130.

Holguin, J., Yushimito, W. F., Aros-Vera, F., \& Reilly, J. J. (2012). User rationality and optimal parkand-ride location under potential demand maximization. Transportation Research Part B: Methodological, 46(8), 949-970.

Hou, B., Zhao, S., \& Liu, H. (2020). A combined modal split and traffic assignment model with capacity constraints for siting remote park-and-ride facilities. IEEE Access, 8, 80502-80517.

Huang, K., Zhu, T., An, K., Liu, Z., \& Kim, I. (2019). Analysis of the acceptance of park-and-ride by users. Journal of Transport and Land Use, 12(1), 637-647.

Islam, S. T., Liu, Z., \& Sarvi, M. (2015). Park-and-Ride network design in a bi-modal transport network optimizing network reliability. Paper presented at the Australasian Transport Research Forum (ATRF), Sydney, New South Wales, Australia.

Karamychev, V., \& van Reeven, P. (2011). Park-and-ride: Good for the city, good for the region? Regional Science and Urban Economics, 41(5), 455-464.

Li, J.-Q., Zhou, K., Zhang, L., \& Zhang, W.-B. (2010). A multimodal trip planning system incorporating the park-and-ride mode and real-time traffic/transit information. Paper presented at the ITS World Congress, Washington, DC.

Liu, Z., Chen, X., Meng, Q., \& Kim, I. (2018). Remote park-and-ride network equilibrium model and its applications. Transportation Research Part B: Methodological, 117, 37-62.

Lu, X.-S., \& Guo, R.-Y. (2015). A bi-objective model for siting park-and-ride facilities with spatial equity constraints. Promet-Traffic and Transportation, 27(4), 301-308.

Martin, P. C., \& Hurrell, W. E. (2012). Station parking and transit-oriented design: Transit perspective. Transportation Research Record, 2276(1), 110-115.

Mock, A., \& Thill, J.-C. (2015). Placement of rapid transit park-and-ride facilities. Transportation Research Record, 2534(1), 109-115.

Niles, J. S., \& Pogodzinski, J. (2016). Bus transit operational efficiency resulting from passenger boardings at park-and-ride facilities. San Jose, CA: Mineta Transportation Institute Publications.

Palakurthy, R., Tung, L.-W., Cryer, L., \& Bell, L. (2017). Trip generation rates at park-and-ride facilities with regional bus and light rail service: A supplement to ITE trip generation data. Transportation Research Record, 2651(1), 60-70.

Pang, H., \& Khani, A. (2018). Modeling park-and-ride location choice of heterogeneous commuters. Transportation, 45(1), 71-87.

Péladeau, N. (2004). QDA miner qualitative data analysis software, user's guide. Montreal: Provalis Research.

Provalis Research. (2014). WordStat 7 User's Guide. Montreal: Provalis Research.

Rajman, M., \& Vesely, M. (2004). From text to knowledge: Document processing and visualization: A text 
mining approach. Text mining and its applications (pp. 7-24). Berlin: Springer.

Sheffi, Y. (1985). Urban transportation networks (Vol. 6). Englewood Cliffs, NJ: Prentice-Hall.

Song, Z., He, Y., \& Zhang, L. (2017). Integrated planning of park-and-ride facilities and transit service. Transportation Research Part C: Emerging Technologies, 74, 182-195.

Stieffenhofer, K. E., Barton, M., \& Gayah V, V. (2016). Assessing park-and-ride efficiency and user reactions to parking management strategies. Journal of Public Transportation, 19(4), 5.

Tennøy, A., Hanssen, J. U., \& Øksenholt, K. V. (2020). Developing a tool for assessing park-and-ride facilities in a sustainable mobility perspective. Urban, Planning and Transport Research, 8(1), 1-23.

Truong, L. C., \& Marshall, W. E. (2014). Are park-and-rides saving the environment or just saving parking costs? Case study of Denver, Colorado, light rail system. Transportation Research Record, 2419(1), 109-117.

VDOT. (2018). Park and ride design guidelines. Retrieved from https://www.virginiadot.org/travel/resources/parkAndRide/Park_Ride_Design_Guidelines.pdf

Wang, H., Meng, Q., \& Zhang, X.-N. (2014). Park-and-ride network equilibrium with heterogeneous commuters and parking space constraint. Transportation Research Record, 2466(1), 87-97.

Wang, H., Meng, Q., \& Zhang, X.-N. (2015). Optimal parking pricing in many-to-one park-and-ride network with parking space constraints. Transportation Research Record, 2498(1), 99-108.

Webb, A., \& Khani, A. (2020). Park-and-ride choice behavior in a multimodal network with overlapping routes. Transportation Research Record, 0361198120908866.

Zhang, D. (2014). Spatial distribution of park-and-ride demand (doctoral dissertation), University of Delaware, Newark, DE.

Zhang, R., Yao, E., \& Pan, L. (2019). Optimizing EV-based P\&R subsidy policies for commuting corridor based on cross-nested logit model. International Journal of Sustainable Transportation, 13(7), 461-478.

Zhao, X., Chen, P., Jiao, J., Chen, X., \& Bischak, C. (2019). How does 'park and ride'perform? An evaluation using longitudinal data. Transport Policy, 74, 15-23. 